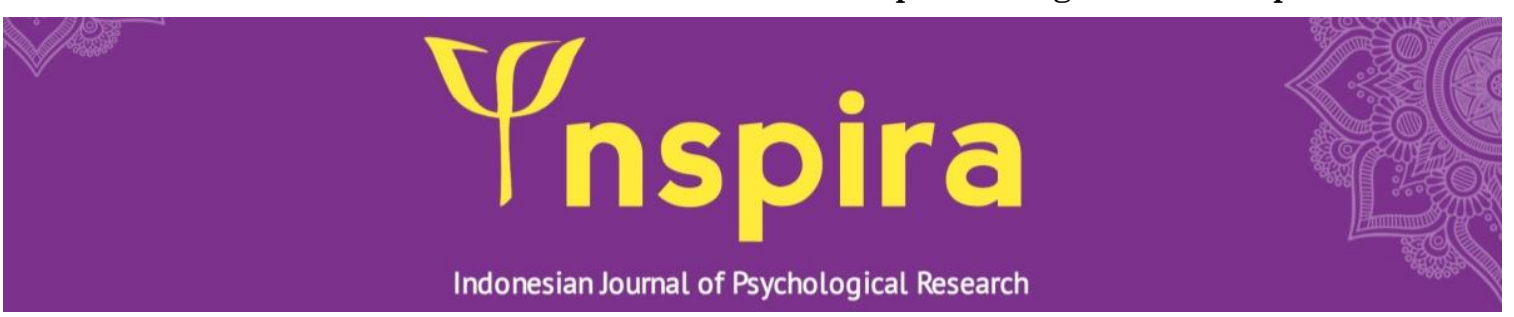

\title{
The difference of orphanages' happiness based on gender
}

Nur Afni Safarina ${ }^{1 凶}$, Nurmaulidina Nasution ${ }^{2}$

${ }^{12}$ Department of Psychology, Universitas Malikussaleh, Aceh, Indonesia;

\section{$\triangle$ Corresponding author:}

Nur Afni Safarina (email: nurafni.safarina@unimal.ac.id)

Abstract - This study aims to determine the differences in happiness in orphanages in terms of gender. This research uses quantitative research methods through a questionnaire for data collection, then a test is carried out to provide an overview of the research variables. The data collection method in this study uses one scale, namely, the scale of happiness. Analysis of data using the T 2 Test Sample Free technique. The participants of this study were 50 children from Miftahul Jannah Orphanage. In terms of the sex of participants for girls taken from the middle-high school range of 25 people, while for men taken from the middle-high school range is as many as 25 people. The results of this study are based on the "Independent Sample Test" output table in the "Equal Variances Assumed" section known to the value of sig. (2-tailed) of $0.83>0.05$. This means there is no difference between man's happiness and women's happiness " at the Miftahul Jannah Orphanage.

\section{Article History:}

Received: January 5, 2020

Revised: February 1, 2020

Accepted: March 3, 2020

Published: June 18, 2020

\section{Keyword:}

adolescents; gender; happiness; orphanage.

How to cite (APA $7^{\text {th }}$ Edition)

Safarina, N. A., \& Nasution, N. (2020). The difference of orphanages' happiness based on gender. INSPIRA: Indonesian Journal of Psychological Research, 1(1), 6-12. https://doi.org/10.32505/inspira.v1i1.1717 


\section{INTRODUCTION}

Emotion is an outpouring of human feelings. Emotions greatly affect human life. Emotions give color to human life. There are two kinds of emotions reviewed from the influence it produces. These forms of emotions are positive and negative emotions. Both of these emotions can be felt by each individual. Negative emotions are described by feelings of fear, sadness, anger, dislike, and other negative feelings, while positive emotions are the opposite (Seligman, 2005).

One form of positive emotion is happiness. Happiness has a positive effect on humans. Yulia (2012) said that happiness is a state of mind or a feeling of pleasure and tranquility of life in a meaningful birth and mind to improve self-function. A happy individual experiences tranquility in his or her life, thus feeling precious, both for himself and others.

Every individual must have the same goal in his or her life. One of these goals is the achievement of happiness. Richards (in Puspitorini, 2012) explains that the highest purpose of life that individuals want is to be rich and happy. Happiness is not only felt by the rich who have everything. A happy individual is an individual who is willing to be grateful for what he or she has.

Ardian \& Nashori (2008) who researches happiness in people with disabilities, suggests that if job satisfaction, love and marriage, and social relations can not be fulfilled, then gratitude will bring submission. Therefore, individuals can take wisdom from existing problems and then form beliefs and expectations that make people with disabilities able to live life and achieve happiness factors that can not be fulfilled. This is reinforced by the results of Rodney and Jaredm's research (2008) which explained that religious individuals tend to have feelings of gratitude to enjoy mental and physical health better. Many factors affect happiness. Putri \& Yuniarti (2011) revealed in their research that overall the events that make the happiest are family-related events. While other responses establish that loving and being loved is an event that makes happiness, spirituality, friends, free time, earn money, as well as other answers, fall into the category of "others". Based on the research, it was revealed that happy events come from events together with family as the closest environment which is then followed by other factors.

Being happy is the ideal feeling that every human being wants. Therefore individuals compete with each other for happiness. King, et al. (Michael Argyle, 2001) says that happiness and the meaning of life are judged as more important than money in producing a good life, more than moral goodness, and even more than going to heaven. In other words, happiness is an important thing to have compared to the money and goodness that individuals have done. Happiness also knows no gender, but the orientation of happiness in adolescent boys and girls varies. Following the results of research conducted by Yulia Woro Puspitorini (2011) that the events that make teenage male respondents very happy are events related to achievement, spirituality, friends, and leisure. As for teenage girls, family-related events, love and love, and money. But in Seligman's research (2005) it was found that women are happier and the same time sadder than men.

This is because women are more expressive in responding to an event that occurs in their lives. Over time, individual needs grow. Individual needs affect the happiness obtained from the satisfaction of fulfillment of needs. 
Hurlock (1997) reveals that important factors in adulthood are in the areas of family life, friendship, rich cultural life, society, and pleasures in life. While children and adolescents are more concerned with popularity and self-acceptance in the environment of their friends.

Happiness as a positive emotion obtained through shortcuts will reduce the value of happiness itself. These shortcuts make individuals become other persons. As revealed by Seligman (2005) that if positive emotions are separated from the use of character will lead to falsehood, emptiness, depression, and in line with the age of man, there is a disturbing awareness of the heart that is in the form of anxiety throughout human life. Such pseudo-happiness can cause anxiety for individuals in living life.

The presence of negative experiences can also cause negative emotions. Individuals who live by trying to be what others want will make the individual have a distorted concept of self. As a result, the experience experienced by individuals who are not in harmony with the concept of self will cause anxiety (Farozin \& Fathiyah, 2004). The lack of happiness makes the individual moody and like to isolate themselves from the surrounding environment. When somber, individuals become easily suspicious, aloof, and defensively focused on their own needs, whereas selfishness is more a characteristic of sadness than happiness (Seligman, 2005). The lack of happiness experienced by individuals results in personality and social life being disrupted.

Unhappiness leads to the destruction of self-adjustment both socially and personally (Hurlock, 1997). Unhappy individuals have negative judgments about themselves as well as those around them. Therefore, less happy individuals have poor self-adjustment. If this continues to happen, then the individual may experience the failure of developmental tasks, especially in the personal and social aspects.

\section{RESEARCH METHOD}

The research approach used in this research is descriptive quantitative research. Descriptive research is a study to gather information about the status of existing symptoms, namely the state of symptoms according to what they were at the time of the study (Arikunto, 2005). In addition, it is called descriptive quantitative research because this type of research produces data in the form of numbers and which is then analyzed statistically. This study uses a type of survey research. Sukmadinata (2006) explained that survey research is used to collect data related to attitudes, values, beliefs, opinions, stances, desires, ideas, behaviors, habits, and so forth.

Donald Ary, et al (in Arikunto 2005), surveys can be conducted to collect data of real nature. The data collected in this study is the happiness of Miftahul Jannah orphanage children with a range of junior high schools.

This research was conducted at Miftahul Jannah Orphanage for approximately one month during October 2019. The happiness scale is shared on a specific sample randomly. The participants of this study were 50 children of Miftahul Jannah orphanage. Judging from the gender of participants for girls taken from the range of junior high school as many as 25 people, while for men taken from the range of junior high school is as many as 25 people.

The research instrument was a tool used to measure natural and social phenomena observed (Sugiyono, 2010). The research instrument used is a questionnaire (questionnaire) scale modification Likert. The research instrument was used in the form of the Happiness Scale. This scale is based on the theoretical study of aspects of happiness and adapted based on the 
Subjective Happiness Scale created by Sonja Lyumbormirsky and Satisfaction with Life Scale compiled by E. Diener.

This study used a scale with a Type Likert scale. The Likert scale is used to measure the attitudes, opinions, and perceptions of a person or group of people about social phenomena (Sugiyono, 2011). Sugiyono (2010) explained that with the Likert scale, the variables to be measured are described as variable indicators. The selection of answer scales in this study used a Likert scale model with 5 answer options. The scale of the answer is Very Appropriate (SS), Appropriate (S), Less Appropriate (KS), Not Appropriate (TS), and Very Inappropriate (STS).

For data analysis, this study employed the independent t-test. These techniques were used to find out the difference between males and females as the differentiating factor.

\section{RESULT}

The Mann-Whitney test is a nonparametric test that does not require normal data distribution. The Mann-Whitney test was used to test whether there were differences between two independent sample groups. This test is often used as a substitute alternative to the Independent t-test if the data is abnormal or used to test differences if the data is an ordinal scale. Based on the analysis, it is known that the variable of happiness spreads following the normal spread that is distributed by the principle of normal curves. As a criterion if $p>0.05$, then the spread is declared normal. Conversely, if the $\mathrm{p}<0.05$, then the spread is not normal (Hadi, 2000).

The linearity test is a required test that is usually done if going to do an analysis or intended to find out the degree of variable relationship Happiness reviewed from the sex in orphanage children. As a criterion, if the $\mathrm{p}$ difference $<0.05$ then it is stated to have a linear degree of relationship (Hadi, 2000).

Table 1 Linearity Test

\begin{tabular}{ccc}
\hline Variable & $\mathbf{F}$ & p-value \\
\hline Happiness & 0,38 & 0,855 \\
\hline
\end{tabular}

Thus, based on the linearity test the relationship can be seen from the variable above has a linear degree of relationship.

As a requirement test if going to do a free sample t-test (Independent Sample t-test) and a one-way variant test (One Way Anova). Test this to see if multiple variants of the data population are the same or not. If the significance value is more than 0.05 then it can be said that the variants of two or more data groups are the same.

Table 2 Homogeneity Test

\begin{tabular}{cccc}
\hline Levene Statistic & $\mathbf{d f 1}$ & $\mathbf{d f 2}$ & Sig. \\
\hline .231 & 1 & 48 & .633 \\
\hline
\end{tabular}

The homogeneity test is used as a requirement test if going to conduct a free sample T-test (Independent Samples t-test) and a one-way variant test (One Way Anova). Test this to see if multiple variants of the data population are the same or not. If the significance value is more than 0.05 then it can be said that the variants of two or more data groups are the same. 
Table 3 Independent Samples Test

\begin{tabular}{ccccc}
\hline & F & Sig & $\begin{array}{c}\text { Sig } \\
(2 \text {-tailed })\end{array}$ & $\begin{array}{c}\text { Mean } \\
\text { Difference }\end{array}$ \\
\hline $\begin{array}{c}\text { Equal variances } \\
\text { Assumed }\end{array}$ & .231 & .633 & 0,83 & -9.760 \\
$\begin{array}{c}\text { Equal variances } \\
\text { assumed }\end{array}$ & & & 0,83 & -9760 \\
\hline
\end{tabular}

Based on the output table Test of Homogeneity of Variances above, it is known that the pvalue of the happiness variable in children in orphanages is 0.633 . Because of the p-value of $0.633>0.05$, then as the basis of decision making in the homogeneity test above, it can be concluded that the variance of happiness result data in children in orphanages is the same or homogeneous. Based on the result, it can be concluded that $\mathrm{H}_{0}$ was accepted and $\mathrm{Ha}$ rejected, which means there is no difference in happiness between the male and female sexes in the orphanage.

\section{DISCUSSION}

The purpose of this study was to find out the difference in happiness in orphanage children who were reviewed from the gender. The process of conducting research conducted in the orphanage went smoothly following the original planning.

Research conducted by quantitative research method through questionnaires for data collection then conducted a test to give an idea of the research variables. In addition, this measurement aims to determine the accuracy of the results of the study with hypotheses conducted by researchers.

Based on the results of research data testing that has been conducted by researchers, the following will be presented a discussion of the results of research obtained from variables namely happiness. The results of this study illustrate the difference in average happiness in orphanages between men and women who are reviewed from the sex, the average value of happiness for men is 221.16, while for women it is 211.40 .

The results of this study are supported by the top-down theory that explains that happiness is influenced by internal and external factors. Examples of internal factors themselves are like the past, the future, the present, while external factors such as money, marriage, social life, happiness, religion, positive emotions, age, education, gender. This theory explains that the happiness experienced by individuals reviewed by the male gender is related to achievement, spirituality, friends, and leisure time. As for women, namely with family, loved or loved, and money.

Furthermore, the results of the first main effect show based on the output table "Independent Sample Test" in the section "Equal Variances Assumed" known sig value. (2tailed) of $0.83>0.05$, then as the basis of decision making in the independent test sample test can be concluded that Ho was accepted and Ha rejected which means there is no difference in male happiness and women's happiness at Miftahul Jannah Orphanage. 
The results of this study are supported by the theory of happiness also does not know the gender, but the orientation of happiness in adolescent boys and girls varies. Following the results of research conducted by Puspitorini (2011) that the events that make teenage male respondents very happy are events related to achievement, spirituality, friends, and leisure. As for teenage girls, family-related events, love and love, and money.

Happiness arises from the fulfillment of needs or expectations and is the cause or means to enjoy. (Hurlock, 1997). Happiness here is how men and women judge their own lives positively overall. Happiness as a positive emotion in the lives of orphanage children has a diverse impact. As revealed by Seligman (2005) that positive emotions expand intellectual, physical, and social resources.

Happiness helps to manage self-ability to interact with its social environment. In addition, happiness also helps children living in orphanages to achieve a healthy personality to support the fulfillment of their developmental tasks. The findings of the second main effect show from the output of "Independent Samples Test", the table part "Mean Difference" is -9760. This shows the difference between happiness outcomes in male and female sexes with average happiness of 211.40-211.16=-9.760.

The results of this study are supported by a top-down theory that explains that women are happier and at the same time sadder than men. This is because women are more expressive in responding to an event that occurs in their lives (Seligman, 2005). Many factors affect happiness. Oetami and Yuniarti (2011) revealed in their research that overall the events that make the happiest are family-related events, and achievement events. While other responses establish that loving and being loved is an event that makes happiness, spirituality, friends, free time, earn money, as well as other answers fall into the category of "others". Based on the research, it was revealed that happy events come from events together with family as the closest environment which is then followed by other factors. These factors have different tendencies of satisfaction levels. Low levels of satisfaction felt by individuals result in reduced levels of happiness as a form of positive emotions.

Seligman (2005) said that having a positive feeling about someone or something makes us approach it, while negative feelings make us avoid it. Thus, happiness is felt not throughout life or only in some factors of life alone.

\section{CONCLUSION}

From the description above, it can be concluded that happiness has an important role in happiness in daily life. It means a lot that for happiness in life begins to develop positive emotions against all the gifts received, then strives with happiness that is always present and present in daily life.

With the various limitations in this study, there are some suggestions submitted by researchers further to understand and preventive efforts in developing happiness in orphanages. It is necessary to seek a more adequate research design to understand happiness. One of the efforts made is to multiply the variables both free and mediator that serves to explain the factors that affect mental health.

This research uses a quantitative method, so it has limitations in extracting and delivering data. Therefore, it is necessary to consider researching this with qualitative approaches (either 
through observation, interview, or FGD) that can test more adequate causality relationships and find training models capable of developing happiness in orphanages.

\section{REFERENCES}

Arikunto, S. (2010). Prosedur penelitian, suatu pendekatan praktik. Rineka Cipta.

Farozin, M. \& Fathiyah, K. N. (2004). Pemahaman tingkah laku. Penerbit Rineka Cipta.

Hurlock, E. B. (1997). Psikologi perkembangan. Suatu Pendekatan Sepanjang Rentang Kehidupan. Erlangga.

Oetami, P. \& Yuniarti, K. W. (2011). Orientasi kebahagiaan siswa SMA: Tinjauan psikologi indigenous pada siswa laki-laki dan perempuan. Jurnal Humanitas 8(2). 105-113.

Puspitorini, Y. W. (2012). Tingkah laku prososial dan kebahagiaan. Skripsi Publikasi: Fakultas Psikologi Universitas Katolik Soegijapranata

Putra, A. A. \& Nashori, F. (2008). Kebahagiaan pada penyandang cacat tubuh (sebuah penelitian kualitatif). Naskah Publikasi: Fakultas Psikologi dan Ilmu Sosial Budaya Universitas Islam Indonesia

Rahman, P. A. \& Siregar, R. H. (2012). Hubungan religiusitas dengan kebahagiaan pada lansia muslim. Skripsi Publikasi: Fakultas Psikologi Universitas Sumatera Utara.

Santrock, J. W. (2002). Live span development: Perkembangan masa hidup 2. Erlangga

Seligman, M. E. P. (2005). Authentic happiness. Mizan Pustaka

Sugiyono. (2011). Metode penelitian administrasi. Alfabeta.

Sukmadinata, N. S. (2006). Metode penelitian pendidikan. PT. Remaja Rosdakarya

Srark, R. \& Aier, J. (2008). Faith and happiness. Review of Religious Research 50(1), 120-125. 